\title{
The Complexity of Social Capital: The Influence of Board and Ownership Interlocks on Implied Cost of Capital in an Emerging Market
}

\author{
Luciano Rossoni $\mathbb{D},{ }^{1,2}$ Cezar Eduardo Aranha, ${ }^{3}$ and Wesley Mendes-Da-Silva $\mathbb{C}^{4,5}$ \\ ${ }^{1}$ UniGranRio, Rio de Janeiro, RJ, Brazil \\ ${ }^{2}$ Brazilian Institute of Social Research (IBEPES), Curitiba, PR, Brazil \\ ${ }^{3} I B M$ Research, Curitiba, PR, Brazil \\ ${ }^{4}$ Fundação Getúlio Vargas, São Paulo, SP, Brazil \\ ${ }^{5} I^{2}$ Institute of The University of Texas at Austin, Austin, TX, USA
}

Correspondence should be addressed to Luciano Rossoni; lrossoni@gmail.com

Received 3 November 2017; Accepted 16 January 2018; Published 14 February 2018

Academic Editor: Benjamin M. Tabak

Copyright (C) 2018 Luciano Rossoni et al. This is an open access article distributed under the Creative Commons Attribution License, which permits unrestricted use, distribution, and reproduction in any medium, provided the original work is properly cited.

\begin{abstract}
Starting from sociological perspectives on complexity, we show how the social capital of boards and owners networks affects the implied cost of capital of companies listed on Brazilian stock exchange. We specifically show arguments and evidence that the effect of the relational resources found in the direct, indirect, and heterogeneous board's ties reduces the cost of capital while relational resources embedded in shareholder networks increase the cost of capital. Our results show that while the increase in the relational resources of the board reduces the implied cost of capital, an increase in these shared resources in the ownership relationships of the firm increases the cost of financial capital.
\end{abstract}

\section{Introduction}

In this paper we are interested in the effect of two different kinds of relevant complex networks in finance [1-3] on implied cost of capital for the listed companies, particularly in a prominent emerging market, Brazil, which have been the subject of studies on complexity in other disciplines such as epidemiology [4], geophysics [5], ecology [6, 7], and information science $[8,9]$.

In this sense, our paper discusses the relationship between networks of boards of directors of listed companies and the networks of shareholders in the stock market with the implied cost of capital in an emerging market context. Usually, the cost of capital is considered one of the main aspects of a financial decision, not only for investors but also for chief financial officers. Simultaneously, firms in emerging markets work under the high cost of capital related to firms listed in developed markets. In turn, strategies that could reduce the cost of capital are relevant for the whole capital market.
The problem of the cost of capital can be investigated under the logic of complexity $[1,10]$. And looking at complexity in a substantive way, financial market problems should be analyzed by "the relationships, connectivity and interdependence between the internal and external actors, and the various structural influences on the environment in which they operate [...] that we will gain a deeper understanding of the evolution of governance frameworks, and reveal new insights regarding their effectiveness" [10, p. 2].

About this, we used sociological perspectives on complexity to understanding how organizations acquire and manage their relational resources, such as the means by which the social structure has an influence on the allocation of resources [11]. Among these resources, one of the most important is the financial capital, especially for public corporations, whose financing strategies are fundamental to their survival and growth [12].

Such a statement is even more valid in current times since there are those who say that we no longer live in a society of 
organizations: we are now living in a society of investors [13]. For these reasons, the investigation into corporate finance, including the financial cost of capital, has been gaining in prominence in the field of organizational strategy, economic sociology, and corporate governance $[14,15]$.

In view of the above, in this article we analyze the cost of capital by Brazilian publicly quoted companies, accepting that the assessment of such firms and their access to credit takes place against the background of the concrete social relationships in which they are embedded $[12,15,16]$. We therefore seek to assess the cost of capital based on an estimate known as implied, or ex ante, which is based on the forecasts of analysts $[17,18]$, while other studies, like the one by Uzzi [12] and Uzzi and Gillespie [11], were based on ex post estimates, which used the history of the returns achieved.

The ex post estimate has been criticized because of its potential inaccuracy. There are three risks associated with such estimates [19]: (1) a difficulty when it comes to identifying the pricing model of the assets; (2) inaccuracy in estimating factor loadings; (3) inaccuracy in estimating the risk factor premiums. For these reasons, Espinosa and Trombetta [17], starting with the work produced by Gebhardt et al. [20] and Easton and Monahan [21], investigated various ways of estimating the implied cost of capital and reached four plausible dimensions: RIV (the residual income valuation model), PEF (the price to forward earnings model), PEG (the price to earnings growth model), and MPEG (the modified price to earnings growth model). The authors concluded that the use of any of these measures would not alter the result, which led us to use the implied cost of capital measure, estimated by the PEG (price to earnings growth model), because of data availability.

As far as the social relationships that condition the cost of capital are concerned, we first studied the relationships of companies established by their directors, a situation known as board interlock, which occurs when a director or officer of one company has also a seat on the board of another company.

Secondly, we investigated the effect of the relationships established between companies because they have owners in common (ownership interlock). This is because there is a whole range of studies that deal with the board and director interlock [15, 22-26] and ownership interlock [2729], but there are few studies that consider these two types of relationship jointly [30], especially in emerging markets like Brazil.

In the case of the board networks, Davis [31] and Mizruchi [32] point out that the benefits are obvious for corporations because good directors tend to participate in a greater number of organizations, as well as in different groups, and their centrality and position are indicative of their prestige. Furthermore, they tend to suffer greater social pressure to act in a responsible way [31].

Studies also indicate that the best-positioned board directors in the network tend to have a greater capacity for receiving information, resources, and knowledge by way of their privileged access to different, unconnected groups [31]; in other words, they have greater social capital $[26,33,34]$.

Despite the fact that such arguments in favor of the greater centrality and privileged position of the board are convincing, there are controversies as to whether relationships have a positive or negative effect on the conduct and performance of firms [35]. There is evidence of positive results in some studies $[15,36,37]$, just as there is evidence of negative results $[23,38]$.

However, the limitation of these studies lies in the fact that they identify the effects of the privileged position of the boards and their directors by basically using indicators of network centrality and position. What these studies left to one side were the number, type, and availability of the relational resources that these board directors bring to organizations [39].

It is regarding this point that we mainly seek to contribute to the studies of corporate relationship networks: we are interested in analyzing the potential effect of the economic capital-relational resources-that is dispersed among the relationship networks of board directors, since the structure of relationships is not sufficient to explain the effects of the latter on the cost of capital.

In doing so we hope to go further than the investigation undertaken by Uzzi [12] and Uzzi and Gillespie [11], who considered social embeddedness in terms of size, duration, and the complementary nature of the relationships between companies and banks. We also evaluate the effects of the relational resources found in direct, indirect, and heterogeneous relationships, since in the latter there is an assumption that nonredundant ties provide additional advantages [34], without mentioning that the information benefits of the network go beyond its direct ties.

Finally, we also investigated what is called the dark side of networks, in which we present arguments and evidence that the overlapping social capital in ownership relationships, instead of reducing the cost of capital, increases it. This is because cross-ownership relationships may mean that companies form part of a conglomerate with interests and controllers in common. As a negative consequence for investors and creditors, these relationships may be a means by which corporations become involved in dysfunctional transactions between related parties (tunneling), during which both opportunism and conflicts may emerge [40-42].

Given the above, our objective in this study was to analyze how the social capital of boards and owners networks affects the financial cost of capital of companies listed on Brazilian stock exchange, the B3. More specifically, we show arguments that the effect of the relational resources found in the direct, indirect, and heterogeneous board's ties reduces the cost of capital while relational resources embedded in shareholder networks increase the cost of capital.

\section{The Social Capital of Corporations by Board and Ownership Interlocks}

Social capital can be understood as that type of capital that is not owned by an individual player but exists as a potential resource because it is embedded in the networks of relationships and is captured and used by way of social exchange $[43,44]$. Looking at it instrumentally, social capital refers to the idea that an investment in relationships can lead to greater access to a wide variety of resources [43]. 
Therefore, any connection with different networks or groups increases the chances of acquiring advantages [33, 34]. As Nahapiet [44] argues, "those that do best, do so by way of their connections and relationships [...] they are more capable of accessing and benefiting from a range of opportunities and resources that affect their performance" (p. 580). In a simple way Portes [45] points out that "economic capital is in the bank accounts of people, human/cultural capital is in their heads and social capital is in the structure of their relationships" (p. 7).

The social mechanisms that support the advantages of social capital involve [43] greater facility in the flow of information, the influence that the social ties exercise over the agents who take decisions, the accreditation and social support given by relationships, and the strengthening of identity and recognition.

Their dimensions, on the other hand, refer to the structure of social capital per se, in which the embeddedness of the players in the network, the psychosocial and institutional apparatus underlying the relationships, among which are the bases of trust, and finally the volume of economic, cultural, and symbolic capital that is accessible to the players in the network are all considered individually $[43,44,46]$.

To understand the social capital of corporations we should start with the assumption that there is separation between ownership and control, in which the former is represented by their owners or shareholders and the latter by their directors and officers. In the first case, social capital is embedded in the relationship formed between two companies for having joint ownership (interlocking ownership), while in the latter case this capital is accessible from shared officers and directors (interlocking directors and officers).

These different types of the tie can be shared by the same set of companies, which perhaps may have led to literature not differentiating between the effects and consequences in the conduct and performance of corporations. However, does the social capital embedded in these different types of relationship operate in the same way? Our arguments indicate it does not, and that is why we hypothesize about its effects on the cost of capital in a different way.

As far as the board social capital is concerned, Mizruchi [32] found that studies referring to interlocking and the performance of companies give a variety of results, with some authors finding positive associations and others negative, albeit to a slight degree. This was corroborated by a recent review by Johnson et al. [35], which highlights the complexity and contingent character of the phenomenon. Even though there is a great variety of such companies what they have in common are the ways by which their social capital tends to be operationalized.

For example, Davis and Mizruchi [47] analyzed how the restructuring of industry in the United States affected the position of banks in the network. To corroborate their hypotheses, these authors used the network centrality concepts of Freeman and Bonacich to determine the position of each company. He and Huang [48], on the other hand, used the centrality of the directors to generate a differentiation coefficient (Gini coefficient) with the aim of identifying how broad the informal hierarchy is. The authors found that the broader the informal hierarchy was, the better the financial performance was.

In Brazil, Mendes-Da-Silva et al. [36] founded a significant relationship between having a privileged position (network centrality, density, and cohesion) on the board of directors of companies traded on B3's New Market and both market value and the indebtedness of the listed companies. Mendes-Da-Silva [49] subsequently investigated the existence of associations between the positioning of the firm in the network of relationships and the value of the companies.

The author used measures of network centrality (degree, "betweenness," and eigenvector) and found evidence that regarding the value of companies there are optimal levels of centrality. Also in Brazil, Rossoni and Machado-Da-Silva [37] investigated the legitimacy arising from the boards of directors of companies listed on the B3. The authors observed that among the companies listed on the Traditional Market, where there are low levels of governance, the bigger the proportion of structural holes is, the greater the market value is. Conversely, however, the authors found that the greater the board network cohesion by way of the clustering coefficient is, the smaller the market value is. Rossoni and MachadoDa-Silva [37] justified such negative results on the basis that greater cohesion between company boards can increase the risk of opportunism on the part of their directors.

This was not the only negative result found in Brazil: Santos et al. [38] found that the value of companies was jeopardized by high levels of interlocking, particularly in companies in which half or more of their directors are on three or more boards. This was also true for those companies where the CEO sits on other boards. This result is corroborated by Fracassi and Tate [23] in their analysis of 1500 companies that comprise the Standard \& Poor's index. According to the authors, the ties of the $\mathrm{CEO}$ reduce the value of the firm, especially in the absence of other governance mechanisms.

Despite the contradictory results, we still insist that relationships between boards can help explain the effectiveness of corporations, especially their cost of capital. First, because we have elements for this, as Mizruchi et al. [15] point out, there is historical evidence among American corporations that relationships between executives and members of the boards of companies are associated with the debt levels of the latter.

In line with such findings, Uzzi [12] showed how small firms can benefit from close relational ties with banks when the size and complementary nature of the undertaking's network are associated with a greater facility when it comes to borrowing capital. Uzzi [12] and Uzzi and Gillespie [11] also found that time, multiplexity, and a complementary nature reduce the cost of capital to a great degree.

Secondly, because we believe that due attention has not been paid to a fundamental dimension of social capital, the resources exist in social relationships [39]. As Lin [43] advocates, the social capital is present in the exchanges that arise from relationships between players by way of the resources that are mobilized and available in such relationships. In other words, if social capital is made up of resources and relationships, it makes no sense to pay attention to only one dimension and ignore the other. Thus, we propose that access 
to and the use of the resources found in the networks between boards and directors can lead to better conditions for raising capital when compared with those that are lacking in such relational resources, which in turn reduces the cost of capital [50].

Looking at the information mechanisms underlying this process, there are indications that the relationships between firms by way of their directors and officers may facilitate, for example, access to lower capital interest rates. In many cases, these firms look for direct financing from sources of funds or credit markets that are little known [12]. There are also motivational benefits embedded in these relationships, in which the ties of trust enable exchange and reciprocity, which are not available in simple market interactions.

Furthermore, having directors who are part of very valuable companies may lead to a firm having greater bargaining power with its creditors, without considering the fact that this may generate a greater number of alternatives, in which these two elements, in both cases, affect the probability of a firm managing to get hold of cheaper financial capital, which implies a lower cost of capital [11].

Finally, knowing that the advantages of relational resources in terms of information and influence can go beyond the direct relationships [34], we advocate that indirect relationships may also be potential catalysts of the benefits we have here described. Such advantages may also reduce the cost of capital of the companies investigated. This being so and given these arguments, we state the following.

Hypothesis 1a. The larger the amount of relational resources available in the direct relationships of the board is, the smaller the company's cost of capital is.

Hypothesis $1 b$. The larger the amount of relational resources available in the indirect relationships of the board is, the smaller the company's cost of capital is.

In addition to the relational resources present in direct and indirect relationships between boards, we also advocate that those present in weak, less redundant, and more heterogeneous ties also affect the reduction in the cost of capital [50]. This is because, as Burt [33, 34] stresses, structural holes or nonredundant ties are opportunities to broker the flow of information and resources between players that are on opposite sides or at little-connected points in the network, and who may have information that has greater innovative content.

As the literature about company boards points out, such characteristics can be of advantage to publicly quoted companies. For example, Kim [26] analyzes the effects of the proportion of the number of outside board members as vectors of the social capital on market value. He points out that such ties have the capacity to extract valuable resources from the environment. In Brazil, Rossoni and Mendes-DaSilva [51] and Rossoni and Machado-Da-Silva [37] used the proportion of nonredundant ties as one of the indicators of the legitimacy of the board. Rossoni et al. [50], using board's social capital ideas, showed that heterogeneous relational resources have a stronger and more significant influence than the resources available from board's direct ties. In the first case, the data suggest that companies that have boards with a greater proportion of structural holes tend to have less systematic risk in the presence of other governance mechanisms (premium listing: New Market). In the second case, nonredundant ties were associated with greater market value only if there were special levels of governance safeguard in place. In the third case, relational resources present in heterogeneous relations have a greater impact on market value.

With regard to the effects on the cost of capital specifically, there is no evidence of this in literature, although Uzzi [12] indicated that an optimal level between transactions with a greater number of banks (opening) and a smaller number (closing) reduces the cost of capital. Given such results, even though some of them are conditioned by institutional factors, we believe that the mechanisms operating in the structural holes are also valid for the cost of capital, especially considering the value of the resources dispersed in these heterogeneous relationships. For these reasons we consider the following.

Hypothesis 2. The larger the heterogeneity of relational resources available in the direct relationships of the board is, the smaller the company's cost of capital is.

All the previous arguments could be valid too for the effects of social capital on the cost of capital arising from ownership relationships because such relationships are associated with those of the board [30]. However, if the relationships are of another type, there is evidence that they operate differently $[15,35]$. In our case, we argue that the overlapping social capital in ownership relationships presents another side, which is, in fact, contrary to the side of the relationships between boards: the dark side of networks.

To make the link with such a statement we need to understand the nature of such relationships. First of all, as Kim [29] points out that the interlinking of owners may mean that the companies form part of the same group, or a conglomerate, which has interests and controllers in common even though they are different companies. This can create the opportunity for the corporations to carry out dysfunctional transactions between related parties (tunneling), in which both opportunism of the controller and conflicts may emerge, especially when there are minority shareholders in some units, but not in others [40-42].

There is also the fact that the diversification of property, especially nonrelated property, is associated with the growth of the firm beyond the point where it maximizes the value of its shares, which offers opportunities for the controllers to misuse the resources [52]. Furthermore, some of these tactics may complicate the effectiveness of corporate governance, by compromising the monitoring of managers and controllers, which might lead to acquisitions and contracts that give a lower return or have obscure interests.

There is a vast amount of documentation of cases of firms whose assets are undervalued due to the discount given by investors because they are part of a conglomerate $[13,53]$. For these reasons, we understand that investors and creditors, in addition to negatively assessing the assets of companies that 
establish such relationships, also see that the cost of capital is greater, given the enhanced underlying risk of operating with such companies. Add to this the fact that the greater the resources shared by a network of owners are, the greater the chances of expropriation or tunneling are. Thus, we then have our final hypothesis.

Hypothesis 3. The larger the amount of relational resources available in firms with cross-ownership with the company is, the greater the cost of capital is.

\section{Method}

3.1. Data and Sample. The population of this study comprises companies listed on the $B 3$, the Brazilian stock exchange, in the years 2010 and 2011 (after 2008-2009 American subprime crises). Although B3 has more than 300 companies with market liquidity, only a small part is covered by market analysts. For this reason, our sample involved 62 companies totaling 114 valid cases, organized into an unbalanced panel.

The dependent variable, the implied cost of capital, that was collected considering $t+1$ years, is formed from the prediction of these analysts, in which not all companies are relevant to the rating agencies. The coverage by analysts refers to costs that are not always offset when the companies are smaller or when the volume of the shares traded is lower. After we had identified the companies covered by market analysts and organized the market previsions by company, we consolidated the financial data obtained from the Economatica ${ }^{\circledR}$ database with the other sources of register data: CVM's disclosure system (Brazil's SEC); information from $B 3$, the Brazilian stock exchange; and the reference forms from the companies.

3.2. Board and Cross-Ownership Networks. We put together the network of company boards based on information available in the reference forms of the listed companies identified in the CVM system. First, we listed all the firms and their respective directors and officers individually for the years 2010 and 2011, which allowed us to generate an incidence network in the 2-mode format (companies versus directors) for each year. We then used PAJEK software to create the relationship networks between boards (1-mode format), in which two firms that were directly linked shared at least one director or officer, a phenomenon known as board interlocking.

These data about board networks were exported to UCINET software, which was used to generate the relational indicators at the firm level, which were subsequently incorporated into the panel. To create the cross-ownership company networks, the same sequence of steps described above was used, but we considered that two companies are interrelated if they have the same owners in the list of shareholders available on the CVM system or if one of them holds shares in the other.

\subsection{Dependent Variable}

3.3.1. Implied Cost of Capital. In line with a study by Espinosa and Trombetta [17], this measure was operationalized in the estimate of the implied cost of capital, or cost of capital ex ante, for the years 2011 and 2012, using

$$
r P E G=\frac{\widehat{x}_{t+2}-\widehat{x}_{t+1}}{\left(r_{e}\right)^{2}},
$$

with $\widehat{x}_{t+r}$ being the forecasts of the consensus analysts of the EPS (earnings per share) for the following first, second, and third years. Beyond year $t+3$, gains are estimated by the linear disappearance of the true ROE (return on equity) for a measure of market ROE for year $t+12$ [17, 20, 21]. In our sample the cost of capital varied between 0.033 (3.3\% a year) and $0.378(37.8 \%)$, with an average of $0.148(14.8 \%)$. Table 1 lists descriptive statistics and correlations of all variables used in this study.

\subsection{Independent Variables}

3.4.1. Social Capital of the Board. Using the same strategy that Rossoni et al. [50], we operationalized the social capital by the sum of the relational resources present in three types of relationship: direct, indirect, and heterogeneous. Thus, to arrive at the social capital of the direct relationships, we first identified for each year the direct ties that each firm had with the others by way of board networks, which are known in the vocabulary of social network analysis as "ego-networks." After this, we identified the market value (total value of the shares traded on the stock exchange) of each of the firm's relationships, which is what we call relational resources. Finally, we added the value of these relational resources for each tie, which generated our social capital indicator of the company's direct relationships. To get a better idea of this, the average value of the direct relational resources was around $\mathrm{R} \$$ 21 billion (nearly U\$ 9 billion). Companies like Vale (biggest metal and mining Brazilian company), for example, had a value of R\$ 120 billion (U\$ 52 billion), while the biggest social capital of the board's direct relationships was that of the board of Embraer, the Brazilian aircraft manufacturer ( $\mathrm{R} \$ 374$ billion or U\$ 163 billion).

The social capital of the indirect relationships of each firm, on the other hand, as the term itself implies, was obtained by way of the sum of the relational resources (market value) of the first-degree indirect relationships. Despite the similarity with the previous measure, social capital by indirect relationships was generated estimating the geodesic distance between the firms and saved it in a distance matrix. We then encoded the first-degree indirect relationships network (value two in the network) on a binary code with the value 1 , while all the other distances were codified as zero. Finally, we add the market value of each indirect relationship with each company to obtain the social capital proxy of the indirect ties.

Finally, the social capital of heterogeneous relationships was generated in the following way: First, we ran the structural holes procedure in UCINET and saved the DR (dyadic redundancy) matrix, which gives the degree of redundancy of each alter (direct relationship) in relation to each of the egos (firms) in the network. Redundancy indicates the percentage of ties that the ego and alter have in an ego network, in which the greater the value is, the more redundant the tie is [33]. 
TABle 1: Descriptive statistics.

\begin{tabular}{|c|c|c|c|c|c|c|c|c|c|c|c|}
\hline & Mean & SD & 1 & 2 & 3 & 4 & 5 & 6 & 7 & 8 & 9 \\
\hline (1) Cost of capital & 0.148 & 0.071 & & & & & & & & & \\
\hline $\begin{array}{l}\text { (2) Social capital of } \\
\text { the board: direct } \\
\text { relationships }\end{array}$ & 21.966 & 50.982 & -0.078 & & & & & & & & \\
\hline $\begin{array}{l}\text { (3) Social capital of } \\
\text { the board: indirect } \\
\text { relationships }\end{array}$ & 73.244 & 12.192 & 0.052 & $0.301^{* *}$ & & & & & & & \\
\hline $\begin{array}{l}\text { (4) Social capital of } \\
\text { the board: } \\
\text { heterogeneous } \\
\text { relationships }\end{array}$ & 14.421 & 35.257 & -0.050 & $0.935^{* *}$ & $0.323^{* *}$ & & & & & & \\
\hline $\begin{array}{l}\text { (5) Social capital: } \\
\text { cross-ownership }^{\text {a }}\end{array}$ & 42.639 & 102.803 & 0.014 & $0.404^{* *}$ & $0.285^{* *}$ & $0.401^{* *}$ & & & & & \\
\hline (6) Board size & 8.230 & 4.921 & -0.061 & $0.253^{* *}$ & $0.383^{* *}$ & $0.305^{* *}$ & $0.272^{* *}$ & & & & \\
\hline (7) Outsiders & 0.849 & 0.185 & -0.045 & $0.125^{* *}$ & $0.227^{* *}$ & $0.144^{* *}$ & $0.143^{* *}$ & $0.377^{* *}$ & & & \\
\hline (8) Company age (ln) & 2.442 & 1.137 & 0.065 & -0.029 & -0.052 & -0.021 & 0.067 & -0.008 & $-0.171^{* *}$ & & \\
\hline (9) Size (ln of assets) & 14.427 & 2.273 & 0.002 & $0.182^{* *}$ & $0.314^{* *}$ & $0.212^{* *}$ & $0.227^{* *}$ & $0.445^{* *}$ & $0.260^{* *}$ & -0.048 & \\
\hline (10) Leverage & 63.354 & 601.471 & $0.338^{* *}$ & -0.027 & -0.035 & -0.024 & -0.025 & -0.065 & -0.066 & 0.054 & $-0.190^{* *}$ \\
\hline
\end{tabular}

${ }^{* *}$ Correlation is significant at the 0.01 level (1-tailed). Correlation is significant at the 0.05 level (1-tailed). $N=114 .{ }^{a}$ Amounts in billions (R\$).

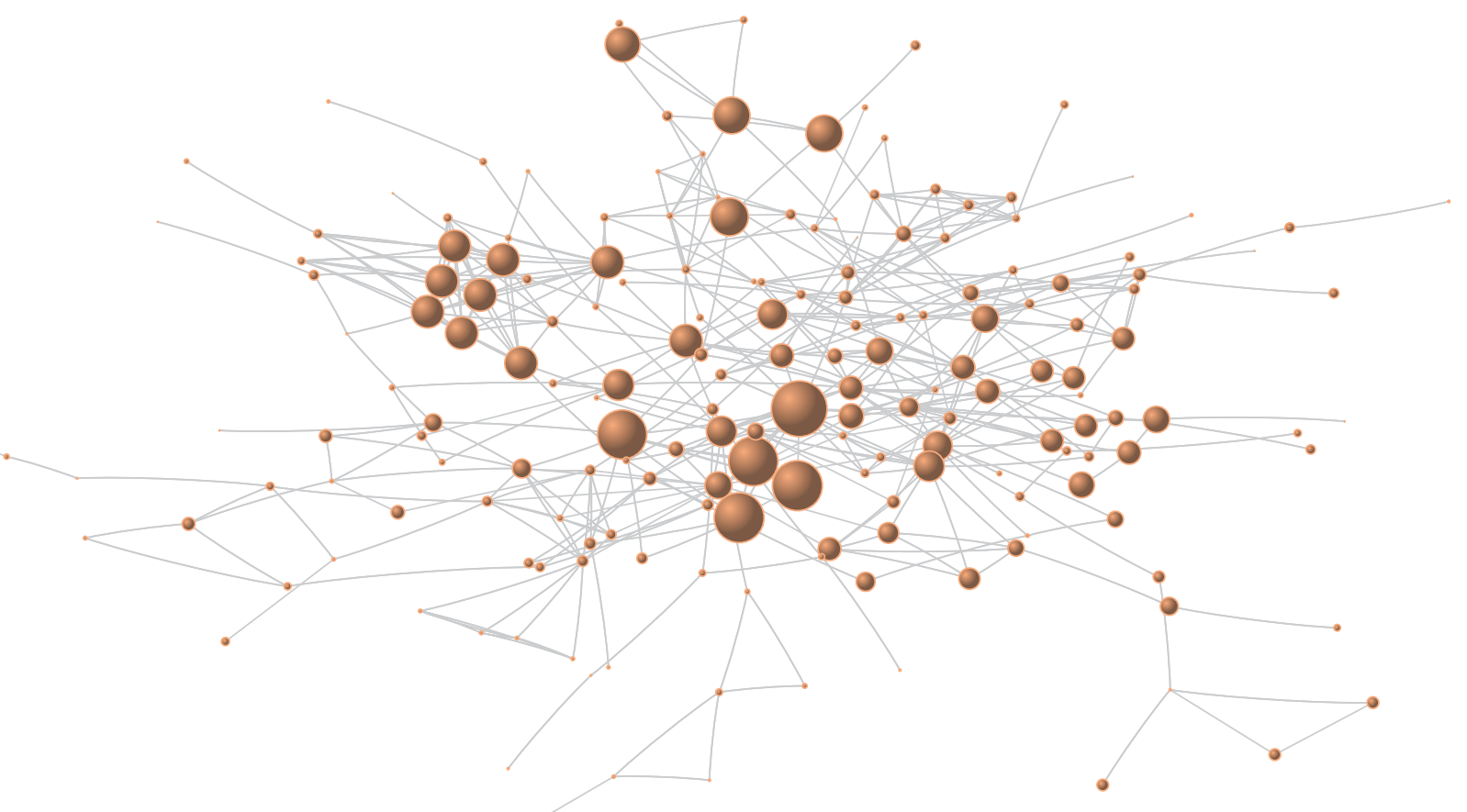

Figure 1: Main component of board interlocking between Brazilian companies. Main component $(n=187)$. Data for the 2010 year. The size of vertices corresponds to the social capital value of companies: the sum of relational resources. Each vertex is one company, and edges indicate board interlocking. Visualization algorithm: Kamada-Kawai, Note. Developed by the authors based on the data collected.

Second, we subtracted the value one from the redundancy score of each valid alter, thus obtaining a heterogeneity score for the alters, which was tabulated in new matrixes. Third, we multiplied the market value of each existing relationship (alter) by its respective heterogeneity score. Finally, we added the product of the relationships of each firm to arrive at the social capital of the heterogeneous relationships of the company.

To illustrate the relationship between the board of directors and the presence of sum of relational resources (a proxy of board's social capital), we put the main component of board interlocking network in Figure 1. 
3.4.2. Social Capital of Cross-Ownership. We also considered the social capital coming from the interlinking between owners since we started from the premise that it might have a different or complementary effect to that of the social capital of the board [30]. Therefore, two firms have a cross-ownership relationship when at least one of them has a shareholding in the other [29]. To arrive at the social capital of the ownership relationships for each of the companies, we identified those that had owners in common or that were shareholders of others [50].

We then identified the market value (total value of the shares traded on the stock exchange) of each of these companies. Finally, we added the market value of each of these companies with cross-ownership, thus forming the social capital proxy of the ownership relationships.

\subsection{Control Variables}

3.5.1. Board Size. Recent studies showed that board size impacts financial variables as market value, risk, and ROA $[38,54]$. Also, it is a relevant characteristic of the board's structure $[23,55]$. Therefore, a higher number of interlocks is more likely on bigger boards. Therefore, we included as control variable the number of board members.

3.5.2. Outsiders. We also controlled the percentage of outside directors between board members. External directors can generate more status, knowledge, and information without interlocking with another company $[35,38,56]$.

3.5.3. Company Age. As other studies have done $[57,58]$, we operationalized the age of the company by way of the natural logarithm of its time of operation on the Brazilian stock exchange, and more specifically on the $B 3$.

3.5.4. Company Size. We used the accounting value of total assets as a proxy for the size of the firm, such information was collected from the Economatica database. Moreover, with the aim of reducing problems of symmetry and kurtosis, we use natural logarithm, as was also done in other similar studies $[36-38,59]$.

3.5.5. Financial Leverage. This is the amount of the total financial debt of the company, divided by its total asset value [60]. We operationalized this measure in accordance with Uzzi [12] and Uzzi and Gillespie [11] because we believe there is a suspicion that indebted companies tend to have a greater cost of capital due to their payment needs.

3.5.6. Year. To avoid problems related to seasonality, such as temporary trends, we controlled the time effect using dummy variables, which is common practice in panel data [60,61]. The 2010 year was considered as the reference category and the 2011 year was identified in the model by way of a dummy variable.

3.5.7. Industry. We controlled the sector effect since there is evidence that it precedes market value [59-61]. To this end we created $s-1$ dummy variables, in which $s$ is the number of players identified in Economatica, considering the "others" sector as a reference category because the former has a larger number of observations.

3.6. Econometric Model. We analyze the influence of board and owners' social capital on the implied cost of capital by panel data analysis, in which the variables were hierarchically incorporated into eight models. We chose the econometric panel model because we had various cases $(N)$ with many observations in time (T), for $N \times T$ observations. We tested three alternatives to evaluate which of them was the most appropriate: (1) grouping the cut-off data based on ordinary least squares (pooled OLS); (2) fixed effects (FE); (3) random effects (RE). According to Greene [62], the choice of the most adjusted model depends on confronting three test hypotheses: (a) the existence, or otherwise, of a single intercept of the transversal cut units (evaluated by way of the Chow's $F$ test); (b) if the variance of the intercept is equal to zero (Lagrange multiplier modified by Breusch and Pagan's proposition); (c) if the estimators are consistent, based on an estimation of the generalized least squares (Hausman test). Based on our evaluation of these hypotheses we chose the best model for each of the relationships between variables.

Then we looked for greater robustness in the results in six different ways. First, we assessed if the dependent variable had serious distribution problems. Second, we assessed if the independent variables had a linear functional form relative to the dependent variable. Third, we assessed if the models had problems of heteroskedasticity using the White test; if they had, we would treat this problem by using robust standard errors. Fourth, we checked for the existence of collinearity problems between the independent variables.

As the social capital of direct relationships was highly correlated with the heterogeneous relationships, we did not regress these variables in the same models. Fifth, we observed if the results remained consistent when we regressed the models without the insignificant control variables, just as we checked if they had the same tendency without the outliers. Sixth, as far as endogeneity is concerned, even if the literature indicated such a problem with indicators related to corporate governance [63] and especially because these elements have both characteristics of self-selection and reverse causality [64], we did not use instrumental variables or simultaneous equations $[60,65]$. This is because there is no clear evidence in the literature about the endogeneity of relational variables $[32,35]$ and because it is not possible to trace a reverse causal nexus between future predictions of analysts, which made up the implied cost of capital, and the independent variables.

\section{Results}

In Table 2 we show the effects of the variables on the implied cost of capital. After the adjustment tests of the panel data (Chow, Breusch-Pagan, and Hausman), the fixed model was the most suitable for all models. The White test indicated problems with heteroskedasticity in all models also, which led us to use the robust standard error.

Following a strategy of hierarchical estimation, in model 1 we show the effect of the control variables on the implied cost of capital. The only control variable that was significant is a 
TABLE 2: Influence of Social Capital on the Implied Cost of Capital (Fixed Panel Data Models).

\begin{tabular}{|c|c|c|c|c|c|c|c|c|}
\hline & Model 1 & Model 2 & Model 3 & Model 4 & Model 5 & Model 6 & Model 7 & Model 8 \\
\hline Board social capital: & & $-0.532^{* * *}$ & & & & $-0.555^{* *}$ & & \\
\hline Direct relationships ${ }^{\mathrm{a}}$ & & $(0.164)$ & & & & $(0.276)$ & & \\
\hline Board social capital: & & & $-0.165^{* *}$ & & & & $-0.162^{* *}$ & \\
\hline Indirect relationships ${ }^{\mathrm{a}}$ & & & $(0.073)$ & & & & $(0.072)$ & \\
\hline Board social capital: & & & & $-0.538^{* *}$ & & & & $-0.585^{*}$ \\
\hline Heterogeneous relationships ${ }^{a}$ & & & & $(0.215)$ & & & & $(0.326)$ \\
\hline Social capital: & & & & & $0.119^{*}$ & $0.115^{* * *}$ & $0.109^{* *}$ & $0.124^{* *}$ \\
\hline Cross-ownership $^{a}$ & & & & & $(0.071)$ & $(0.047)$ & $(0.054)$ & $(0.056)$ \\
\hline \multicolumn{9}{|l|}{ Control variables } \\
\hline \multirow{2}{*}{ Board size } & -0.001 & -0.002 & -0.001 & -0.002 & -0.002 & -0.002 & -0.002 & -0.002 \\
\hline & $(0.002)$ & $(0.003)$ & $(0.002)$ & $(0.003)$ & $(0.002)$ & $(0.002)$ & $(0.002)$ & $(0.002)$ \\
\hline \multirow{2}{*}{ Outsiders } & $-0.336^{* *}$ & -0.222 & $-0.405^{* * *}$ & -0.232 & $-0.341^{* *}$ & $-0.224^{* *}$ & $-0.408^{* * *}$ & $-0.230^{* *}$ \\
\hline & $(0.150)$ & $(0.150)$ & $(0.122)$ & $(0.158)$ & $(0.138)$ & $(0.104)$ & $(0.111)$ & $(0.108)$ \\
\hline \multirow{2}{*}{ Company age (ln) } & 0.039 & 0.056 & 0.041 & 0.053 & 0.051 & $0.071^{*}$ & 0.051 & 0.040 \\
\hline & $(0.039)$ & $(0.044)$ & $(0.037)$ & $(0.046)$ & $(0.039)$ & $(0.036)$ & $(0.038)$ & $(0.040)$ \\
\hline \multirow{2}{*}{ Size (ln of assets) } & 0.028 & 0.005 & 0.047 & 0.011 & 0.012 & -0.003 & 0.040 & -0.005 \\
\hline & $(0.034)$ & $(0.036)$ & $(0.046)$ & $(0.037)$ & $(0.032)$ & $(0.027)$ & $(0.044)$ & $(0.029)$ \\
\hline \multirow{2}{*}{ Leverage } & 0.001 & 0.001 & 0.001 & 0.001 & 0.001 & $0.002^{*}$ & 0.001 & $0.002^{*}$ \\
\hline & $(0.001)$ & $(0.001)$ & $(0.001)$ & $(0.001)$ & $(0.001)$ & $(0.001)$ & $(0.001)$ & $(0.001)$ \\
\hline \multirow{2}{*}{ Constant } & -0.073 & 0.131 & -0.281 & 0.071 & 0.004 & 0.238 & -0.206 & 0.330 \\
\hline & $(0.498)$ & $(0.526)$ & $(0.639)$ & $(0.546)$ & $(0.477)$ & $(0.370)$ & $(0.617)$ & $(0.433)$ \\
\hline White's test & $41.138^{* * *}$ & $47.366^{* * *}$ & $46.774^{* * *}$ & $45.202^{* *}$ & $52.862^{* * *}$ & $57.124^{* *}$ & $58.893^{* * *}$ & $56.957^{* * *}$ \\
\hline Chow's $F$ test & $53.498^{* * *}$ & $54.663^{* * *}$ & $51.044^{* * *}$ & $53.745^{* * *}$ & $53.879^{* * *}$ & $53.198^{* * *}$ & $50.997^{* * *}$ & $74.955^{* * *}$ \\
\hline Breusch-Pagan test & $12.578^{* * *}$ & $13.821^{* * *}$ & $12.646^{* * *}$ & $13.239^{* * *}$ & $12.520^{* * *}$ & $12.100^{* * *}$ & $12.6561^{* * *}$ & $13.341^{* * *}$ \\
\hline Hausman's test & $70.758^{* *}$ & $12.121^{* *}$ & $10.786^{*}$ & $10.014^{*}$ & $11.114^{*}$ & $13.522^{*}$ & $175.47^{* * *}$ & $10.974^{*}$ \\
\hline Akaike's criterion & 353.33 & 374.68 & 362.91 & 365.91 & 354.20 & 378.34 & 363.599 & 366.62 \\
\hline$F$ & $3.24^{* * *}$ & $4.03^{* * *}$ & $3.58^{* * *}$ & $3.69^{* * *}$ & $3.27^{* * *}$ & $4.17^{* * *}$ & $3.60^{* * *}$ & $3.75^{* * *}$ \\
\hline$R^{2}$ overall & 0.837 & 0.868 & 0.853 & 0.857 & 0.841 & 0.874 & 0.856 & 0.862 \\
\hline
\end{tabular}

Standard error in parentheses. Dummies of industry and years omitted. $N=114 ;{ }^{* * *} p<0.01 ;{ }^{* *} p<0.05 ;{ }^{*} p<0.1{ }^{a}$ Amounts in billions (R\$).

percentage of outsiders' directors $(p<0.05)$ : a $1 \%$ increase in this variable is related to a $0.33 \%$ reduction in the cost of capital. This result is coherent with other studies about board structure, evidencing that the bigger the degree of external financing is, the lower the cost of acquiring financial capital is.

Regarding our hypotheses, in models 2 and 6 we find that the larger the number of relational resources (social capital) in relationships directly established by the board is, the lower the cost of capital is, which corroborates hypothesis 1a. The social capital coefficient of direct relationships in model 7 indicates that every $\mathrm{R} \$ 10$ billion (U\$ 3.3 billion) increase in social capital present in the direct relationship leads to a reduction of $0.55 \%$ in the cost of capital. The social capital deriving from indirect relationships also gave a similar effect on the cost of capital; the results were significant both in model $3(p<0.05)$ and in model $7(p<0.05)$, leading us to accept the validity of hypothesis $1 b$.

About the social capital embedded in heterogeneous relationships (structural holes), the data indicate a significant reduction in the cost of capital $(p<0.05$, model $4 ; p<0.05$, model 8), which leads us to corroborate hypothesis 2. Among the three measures of board's social capital, that one composed by the heterogeneous ties had the highest coefficients. Results reinforce the argument that nonredundant links can bring additional benefits in company networks.

Finally, we analyzed the effect of the social capital of crossownership in models 5 to 8 . The effect was significant in all models, leading us to accept hypothesis 3. The data indicate that an increase of $\mathrm{R} \$ 10$ billion (U\$ 3.3 billion) in relational resources coming from cross-ownership is associated with an increase of $0.11 \%$ in the cost of capital. This might seem to be a small percentage, but if we consider the average value of these relational resources we are talking about, for example, $0.56 \%$ of current liabilities, which are around $\mathrm{R} \$ 5$ billion (US 1,65 billion), this would give an average increase in the cost of capital of around R\$ 27 million (U\$ 8.2 million).

\section{Discussion and Conclusion}

In this study, we show that while board's social capital reduces the cost of capital, ownership interlocks' social capital increases the cost of capital of companies listed on the 
Brazilian stock exchange. To this end, we used a different measure to capture companies' social capital founded in the relational resources of direct, indirect, and heterogeneous board ties and in the relational resources embedded in ownership networks.

Regarding the social capital of the board, this study indicated that the resources present in direct, indirect, and heterogeneous relationships significantly reduce the cost of capital of publicly quoted companies listed on the Brazilian stock exchange, showing that the greater the relational resources available via the board are, the lower the cost of capital of the companies is. Therefore, our hypotheses were in line with the perspectives of Chalupnicek [39] and Flap and DeGraaf [66]. We advocated earlier measures of social capital that do not put the relational resources as an essential element of social capital $[39,50]$. Indeed, it is not enough to explain the complexity of the relational phenomenon in financial networks $[1,2]$.

Looking at the heterogeneity of the relationships, we found that structural holes are means for obtaining information and various resources, enabling firms to have a greater competitive advantage, including a bigger market value. However, as we reported previously, more studies will be necessary to assess how much impact the social capital deriving from structural holes has since it was highly correlated with the social capital inherent in direct relationships.

With regard to the social capital present in relationships between owners, our study corroborated the other studies that provide evidence of the agency problems inherent to cross-ownership and their respective conglomerates, whether formal or informal $[13,27,29,52]$. Our data tend to support the statement that firms with cross-ownership are viewed with reservation by investors and creditors because market analysts tend to presume they have a greater cost of capital. Suspicions that there is expropriation or tunneling in the transactions between companies seem feasible. It is worth emphasizing, also, that this effect was only visible when the social capital of the board was included in the model, which highlights the complementary nature between these variables in the investigation of the precedents of the cost of capital, as strongly suggested by Bohman [30].

5.1. Theoretical and Practical Implications. The empirical results of this research make it possible to develop some theoretical and practical implications. The first theoretical understanding has to do with the positioning of the board and its effects on the performance of companies. Various studies use positioning measures of a player in the network to test their research hypotheses or questions, such as small world studies, developed by Brookfield et al. [27], Mendes-Da-Silva [49], and Pusser et al. [67], who studied interlocking between company boards and American universities, or Rossoni and Machado-Da-Silva [37] and Rossoni and Mendes-Da-Silva [51], in their research into legitimacy and market value in companies quoted on the $B 3$. This study produces evidence that the board and owners relational resources have more effect than only board relational position on the cost of capital $[39,50]$.
The second theoretical implication is related to the concept of board interlocking and corporate governance. Davis and Mizruchi [47] state that interlocking can have an economic and social influence on organizations, and Davis [31] identified that interlocking has a social influence on governance practices in the United States. Rossoni and Mendes-Da-Silva [51] found that companies with better quality corporate governance, organizational reputation, and board legitimacy have an influence on the risk of shares traded on the stock exchange. Indeed, this study contributes to the field of board interlocking and corporate governance by studying the analysis of the social capital of the board and providing empirical evidence of how interlocking influences the cost of capital of these companies.

The third theoretical implication is linked to the analysis of the relational resources of the board and their effect on performance. Finegold et al. [68] found evidence that the social capital of the board guarantees that companies receive resources, advice, and better monitoring and are assured of a better performance. Kim [26], using Tobin's $Q$ indicator, produces empirical evidence that the social capital of external board members is positively associated with the market value. Like Rossoni et al. [50], this study contributes to the research into social capital by evaluating the relational resources of the board using the market value (capital) embedded in the network of relationships of companies and innovates by measuring the cost of capital by ex ante estimates. This goes further than other studies, like the one by Kim [26], who measured social capital by way of affiliations in company boards and university governing boards, and by Stevenson and Radin [69], who measured social capital by way of surveys with CEOs.

Finally, as Bohman [30] and Mizruchi et al. [15] advocate, the fourth and last theoretical implication of this study refers to the need to consider that different types of tie have different implications; in the case of ownership relationships, for example, there was indeed an increase in the cost of capital. This highlights the fact that relationships may not always have a positive potential but may also have a negative side [70].

In practical terms, this research is enlightening for investment fund managers, the managers of companies listed on stock exchange in emerging markets like Brazil, and individual investors. By analyzing the components of the board, the network of company owners and the cost of capital fund managers and creditors can evaluate strategies for seeking better composition for their share and debenture portfolios in order to reduce the risk of the funds they manage.

For the managers of companies listed on the stock exchange, the data indicate that board members can be used as the drivers of information about the best capital financing rates. The research draws the attention of individual investors to their need to consider the board in their assessment of a firm, before deciding where to invest their capital.

5.2. Recommendations for Future Studies. The first recommendation for future work is to analyze publicly quoted companies with a view to looking at outsiders, following the concept of Portes [45], to identify how they are affected because of interlocking boards. Corporate governance is 
a topic of great interest and we recommend that a more in-depth evaluation is carried out of social capital at the various levels of corporate governance to assess how the characteristics of each level of governance affect companies.

The network of owners should also be analyzed up to the final level in the structure, in other words, as far as private individual owners. We recommend a more in-depth analysis into the behavior of organizations that, when they experience some difficulty, seek to strengthen their boards by bringing in directors with a better reputation or those who are on boards of companies with a lower cost of capital, with the objective being to provide their organization with greater credibility in the short term, especially if these ties occur between investment funds and banks.

The behavior of independent board members, who leave organizations when the latter get into some difficulty, is also worth analyzing. Thus, their image will not be affected by the companies' problems. Finally, it is also worth using spatial regression and more recent relational statistics methods to evaluate the individual effect of each relational resource and not the sum of their added value at the level of the firm.

\section{Conflicts of Interest}

The authors declare that there are no conflicts of interest regarding the publication of this article.

\section{Acknowledgments}

This work was partially supported by FAPERJ (Grant no. E-26/201.528/2014), the São Paulo Research Foundation (FAPESP) (Grants nos. 2014/26003-9, 2017/09306-60), the National Council for Scientific and Technological Development (CNPq) (Grants nos. 470894/2014-8, 301513/2016-3), and the Fundação Getúlio Vargas (FGV/EAESP) Research Fund 2017.

\section{References}

[1] G. Caldarelli, S. Battiston, D. Garlaschelli, and M. Catanzaro, "Emergence of complexity in financial networks," in Journal of Complex Networks, vol. 650 of Lecture Notes in Physics, pp. 399423, Springer, Berlin, Germany, 2004.

[2] B. M. Tabak, T. R. Serra, and D. O. Cajueiro, "Topological properties of stock market networks: the case of Brazil," Physica A: Statistical Mechanics and its Applications, vol. 389, no. 16, pp. 3240-3249, 2010.

[3] C. K. Tse, J. Liu, and F. C. M. Lau, "A network perspective of the stock market," Journal of Empirical Finance, vol. 17, no. 4, pp. 659-667, 2010.

[4] D. M. Junqueira, R. M. de Medeiros, T. C. N. Ferreira Leite et

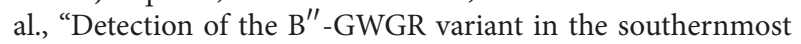
region of Brazil: unveiling the complexity of the human immunodeficiency virus-1 subtype B epidemic," Memórias do Instituto Oswaldo Cruz, vol. 108, no. 6, pp. 735-740, 2013.

[5] M. E. S. Silva, L. M. V. Carvalho, M. A. F. D. S. Dias, and T. D. M. B. S. Xavier, "Complexity and predictability of daily precipitation in a semi-arid region: an application to Ceará, Brazil," Nonlinear Processes in Geophysics, vol. 13, no. 6, pp. 651-659, 2006.
[6] C. Adams, L. Chamlian Munari, N. Van Vliet et al., "Diversifying incomes and losing landscape complexity in quilombola shifting cultivation communities of the Atlantic Rainforest (Brazil)," Human Ecology, vol. 41, no. 1, pp. 119-137, 2013.

[7] F. Papadimitriou, "Modelling landscape complexity for land use management in Rio de Janeiro, Brazil," Land Use Policy, vol. 29, no. 4, pp. 855-861, 2012.

[8] V. M. Netto, J. Meirelles, and F. L. Ribeiro, "Social interaction and the city: the effect of space on the reduction of entropy," Complexity, vol. 2017, Article ID 6182503, pp. 1-16, 2017.

[9] V. C. Barbosa, "Information integration from distributed threshold-based interactions," Complexity, vol. 2017, Article ID 7046359, pp. 1-14, 2017.

[10] M. Goergen, C. Mallin, E. Mitleton-Kelly, A. Al-Hawamdeh, and I. H.-Y. Chiu, Corporate Governance and Complexity Theory, Edward Elgar Publishing, 2010.

[11] B. Uzzi and J. Gillespie, "Corporate social capital and the cost of financial capital: an embeddedness approach," in Corporate Social Capital, J. Lenders and S. Gabbay, Eds., pp. 446-459, Springer, New York, NY, USA, 1999.

[12] B. Uzzi, "Embeddedness in the making of financial capital: how social relations and networks benefit firms seeking financing," American Sociological Review, vol. 64, no. 4, pp. 481-505, 1999.

[13] G. F. Davis, "The rise and fall of finance and the end of the society of organizations," Academy of Management Perspectives, vol. 23, no. 3, pp. 27-44, 2009.

[14] G. F. Davis, "New directions in corporate governance," Annual Review of Sociology, vol. 31, no. 1, pp. 143-162, 2005.

[15] M. S. Mizruchi, L. B. Stearns, and C. Marquis, "The conditional nature of embeddedness: a study of borrowing by large U.S. firms, 1973-1994," American Sociological Review, vol. 71, no. 2, pp. 310-333, 2006.

[16] M. Granovetter, "Economic action and social structure: the problem of embeddedness," American Journal of Sociology, vol. 91, no. 3, pp. 481-510, 1985.

[17] M. Espinosa and M. Trombetta, "Disclosure interactions and the cost of equity capital: evidence from the Spanish continuous market," Journal of Business Finance \& Accounting, vol. 34, no. 9-10, pp. 1371-1392, 2007.

[18] M. Souissi and H. Khlif, "Meta-analytic review of disclosure level and cost of equity capital," International Journal of Accounting \& Information Management, vol. 20, no. 1, pp. 49-62, 2012.

[19] E. F. Fama and K. R. French, "Industry costs of equity," Journal of Financial Economics, vol. 43, no. 2, pp. 153-193, 1997.

[20] W. R. Gebhardt, C. M. C. Lee, and B. Swaminathan, "Toward an implied cost of capital," Journal of Accounting Research, vol. 39, no. 1, pp. 135-176, 2001.

[21] P. D. Easton and S. J. Monahan, "An evaluation of accounting-based measures of expected returns," The Accounting Review, vol. 80, no. 2, pp. 501-538, 2005.

[22] H.-L. Chen, "Board capital, CEO power and R\&D investment in electronics firms," Corporate Governance: An International Review, vol. 22, no. 5, pp. 422-436, 2014.

[23] C. Fracassi and G. Tate, "External networking and internal firm governance," Journal of Finance, vol. 67, no. 1, pp. 153-194, 2012.

[24] T. R. Johansen and K. Pettersson, "The impact of board interlocks on auditor choice and audit fees," Corporate Governance: An International Review, vol. 21, no. 3, pp. 287-310, 2013.

[25] Y. Kim, "Board network characteristics and firm performance in Korea," Corporate Governance: An International Review, vol. 13, no. 6, pp. 800-808, 2005. 
[26] Y. Kim, "The proportion and social capital of outside directors and their impacts on firm value: evidence from Korea," Corporate Governance: An International Review, vol. 15, no. 6, pp. 1168-1176, 2007.

[27] J. Brookfield, S. Chang, I. Drori et al., "The small worlds of business groups: liberalization and network dynamics," in The Small Worlds of Corporate Governance, B. M. Kogut, Ed., pp. 77116, MIT Press, Cambridge, Mass, USA, 2012.

[28] C. F. K. V. Inoue, S. G. Lazzarini, and A. Musacchio, "Leviathan as a minority shareholder: firm-level implications of state equity purchases," Academy of Management Journal, vol. 56, no. 6, pp. 1775-1801, 2013.

[29] D.-W. Kim, "Interlocking ownership in the Korean chaebol," Corporate Governance, vol. 11, no. 2, pp. 132-142, 2003.

[30] L. Bohman, "Bringing the owners back in: an analysis of a 3mode interlock network," Social Networks, vol. 34, no. 2, pp. 275-287, 2012.

[31] G. F. Davis, "The significance of board interlocks for corporate governance," Corporate Governance: An International Review, vol. 4, no. 3, pp. 154-159, 1996.

[32] M. S. Mizruchi, "What do interlocks do? An analysis, critique, and assessment of research on interlocking directorates," Annual Review of Sociology, vol. 22, pp. 271-298, 1996.

[33] R. S. Burt, Structural Holes: The Social Structure of Competition, Harvard University Press, Cambridge, Mass, USA, 1992.

[34] R. S. Burt, Brokerage and Closure: An introduction to social capital, Oxford University Press, New York, NY, USA, 2005.

[35] S. G. Johnson, K. Schnatterly, and A. D. Hill, "Board composition beyond independence: social capital, human capital, and demographics," Journal of Management, vol. 39, no. 1, pp. 232$262,2013$.

[36] W. Mendes-Da-Silva, L. Rossoni, D. M. L. Martin, and R. Martelanc, "A Influência das Redes de Relações Corporativas no Desempenho das Empresas do Novo Mercado da Bovespa," Revista Brasileira de Finanças, vol. 6, no. 3, pp. 337-358, 2008.

[37] L. Rossoni and C. L. Machado-Da-Silva, "Legitimidade, governança corporativa e desempenho: análise das empresas da BM\&F Bovespa," Revista de Administração de Empresas, vol. 53, no. 3, pp. 272-289, 2013.

[38] R. L. Santos, A. D. M. da Silveira, and L. A. Barros, "Board interlocking in Brazil: directors' participation inmultiple companies and its effect on firm value and profitability," Latin American Business Review, vol. 13, no. 1, pp. 1-28, 2012.

[39] P. Chalupnicek, "The CAPITAL in social capital: an Austrian perspective," American Journal of Economics and Sociology, vol. 69, no. 4, pp. 1230-1250, 2010.

[40] M. Bertrand, P. Mehta, and S. Mullainathan, "Ferreting out tunneling: an application to indian business groups," The Quarterly Journal of Economics, vol. 117, no. 1, pp. 121-148, 2002.

[41] Y.-L. Cheung, L. Jing, T. Lu, P. R. Rau, and A. Stouraitis, “Tunneling and propping up: an analysis of related party transactions by Chinese listed companies," Pacific-Basin Finance Journal, vol. 17, no. 3, pp. 372-393, 2009.

[42] Y. E. Riyanto and L. A. Toolsema, "Tunneling and propping: a justification for pyramidal ownership," Journal of Banking \& Finance, vol. 32, no. 10, pp. 2178-2187, 2008.

[43] N. Lin, Social Capital: A Theory of Social Structure and Action, Cambridge University Press, Cambridge, Mass, USA, 2001.

[44] J. Nahapiet, "The role of social capital in inter-organizational relationships," in The Oxford Handbook of Inter-Organizational Relations, S. Cropper, M. Ebers, C. Huxham, and P. S. Ring, Eds., pp. 580-606, Oxford University Press, New York, NY, USA, 2008.

[45] A. Portes, "Social capital: its origins and applications in modern sociology," Annual Review of Sociology, vol. 24, no. 1, pp. 1-24, 1998.

[46] R. Bachmann and A. C. Inkpen, "Understanding institutionalbased trust building processes in inter-organizational relationships," Organization Studies, vol. 32, no. 2, pp. 281-301, 2011.

[47] G. F. Davis and M. S. Mizruchi, “The money center cannot hold: commercial banks in the U.S. system of corporate governance," Administrative Science Quarterly, vol. 44, no. 2, p. 215, 1999.

[48] J. He and Z. Huang, "Board informal hierarchy and firm financial performance: exploring a tacit structure guiding boardroom interactions," Academy of Management Journal, vol. 54, no. 6, pp. 1119-1139, 2011.

[49] W. Mendes-Da-Silva, "Small worlds and board interlocking in Brazil: a longitudinal study of corporate networks, 1997-2007," Brazilian Review of Finance, vol. 9, no. 4, pp. 465-492, 2011.

[50] L. Rossoni, C. E. Aranha, and W. Mendes-Da-Silva, "Does the capital of social capital matter? Relational resources of the board and the performance of Brazilian companies," Journal of Management \& Governance, pp. 1-33, 2017.

[51] L. Rossoni and W. Mendes-Da-Silva, "How does legitimacy operate in emerging capital markets? Investigating the moderating effects of premium listings and firm size on risk," Canadian Journal of Administrative Sciences.

[52] C.-N. Chung and X. Luo, "Institutional logics or agency costs: the influence of corporate governance models on business group restructuring in emerging economies," Organization Science, vol. 19, no. 5, pp. 766-784, 2008.

[53] P. G. Berger and E. Ofek, "Diversification's effect on firm value," Journal of Financial Economics, vol. 37, no. 1, pp. 39-65, 1995.

[54] I. Filatotchev, S. Chahine, and G. D. Bruton, "Board interlocks and initial public offering performance in the United States and the United Kingdom: An institutional perspective," Journal of Management, 2016.

[55] E. M. Fich and A. Shivdasani, "Are busy boards effective monitors?” The Journal of Finance, vol. 61, no. 2, pp. 689-724, 2006.

[56] P. R. Haunschild and C. M. Beckman, "When do interlocks matter? Alternate sources of information and interlock influence," Administrative Science Quarterly, vol. 43, pp. 815-844, 1998.

[57] R. Haniffa and T. E. Cooke, "Culture, corporate governance and disclosure in Malaysian corporations," Abacus, vol. 38, no. 3, pp. 317-349, 2002.

[58] W. Mendes-Da-Silva and L. M. Onusic, "Corporate e-disclosure determinants: evidence from the Brazilian market," International Journal of Disclosure and Governance, vol. 11, no. 1, pp. 54-73, 2014.

[59] B. S. Black, A. G. de Carvalho, and É. Gorga, "What matters and for which firms for corporate governance in emerging markets? Evidence from Brazil (and other BRIK countries)," Journal of Corporate Finance, vol. 18, no. 4, pp. 934-952, 2012.

[60] A. D. M. da Silveira, R. P. C. Leal, A. L. Carvalhal-da-Silva, and L. A. B. D. C. Barros, "Endogeneity of Brazilian corporate governance quality determinants," Corporate Governance: The International Journal of Business in Society, vol. 10, no. 2, pp. 191202, 2010.

[61] J. L. Procianoy and R. Verdi, "Bovespa new markets adoption - novo mercado, nível 1 and nível 2, determinants and consequences," Brazilian Review of Finance, vol. 7, no. 1, pp. 107-136, 2009. 
[62] W. H. Greene, Econometric Analysis, Prentice-Hall, Upper Saddle River, NJ, USA, 2000.

[63] M. B. Wintoki, J. S. Linck, and J. M. Netter, "Endogeneity and the dynamics of internal corporate governance," Journal of Financial Economics, vol. 105, no. 3, pp. 581-606, 2012.

[64] K. Li and N. R. Prabhala, "Self-selection models in corporate finance," in Handbook of Corporate Finance, B. E. Eckbo, Ed., pp. 39-86, Elsevier, Amsterdan, Netherlands, 2007.

[65] B. Black and W. Kim, "The effect of board structure on firm value: a multiple identification strategies approach using Korean data," Journal of Financial Economics, vol. 104, no. 1, pp. 203-226, 2012.

[66] H. D. Flap and N. D. DeGraaf, "Social capital and attained occupational-status," Netherlands Journal of Social Sciences, vol. 22, no. 2, pp. 145-161, 1986.

[67] B. Pusser, S. Slaughter, and S. L. Thomas, "Playing the board game: an empirical analysis of university trustee and corporate board interlocks," The Journal of Higher Education, vol. 77, no. 5, pp. 747-775, 2006.

[68] D. Finegold, G. S. Benson, and D. Hecht, "Corporate boards and company performance: Review of research in light of recent reforms," Corporate Governance: An International Review, vol. 15, no. 5, pp. 865-878, 2007.

[69] W. B. Stevenson and R. F. Radin, "Social capital and social influence on the board of directors," Journal of Management Studies, vol. 46, no. 1, pp. 16-44, 2009.

[70] K. A. Wurthmann, "Service on a stigmatized board, social capital, and change in number of directorships," Journal of Management Studies, vol. 51, no. 5, pp. 814-841, 2014. 


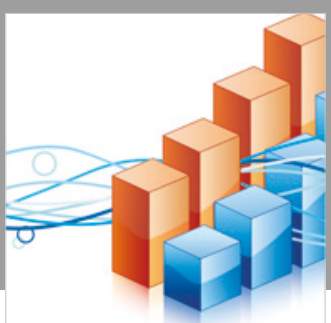

Advances in

Operations Research

\section{-n-m}
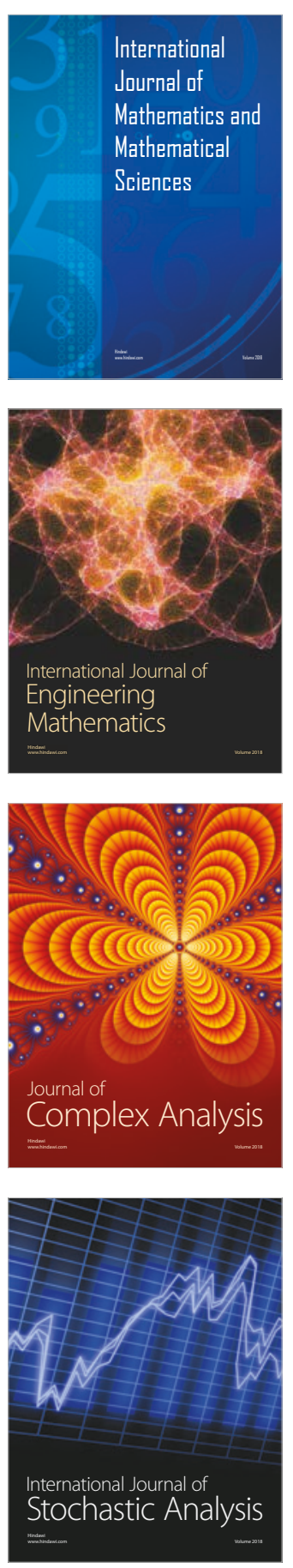
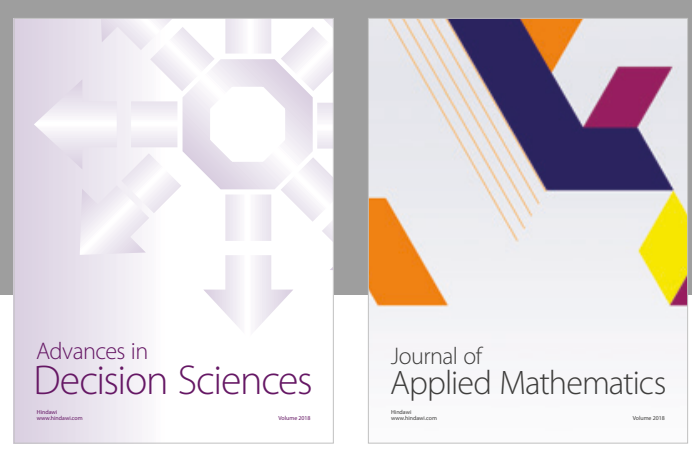

Journal of

Applied Mathematics
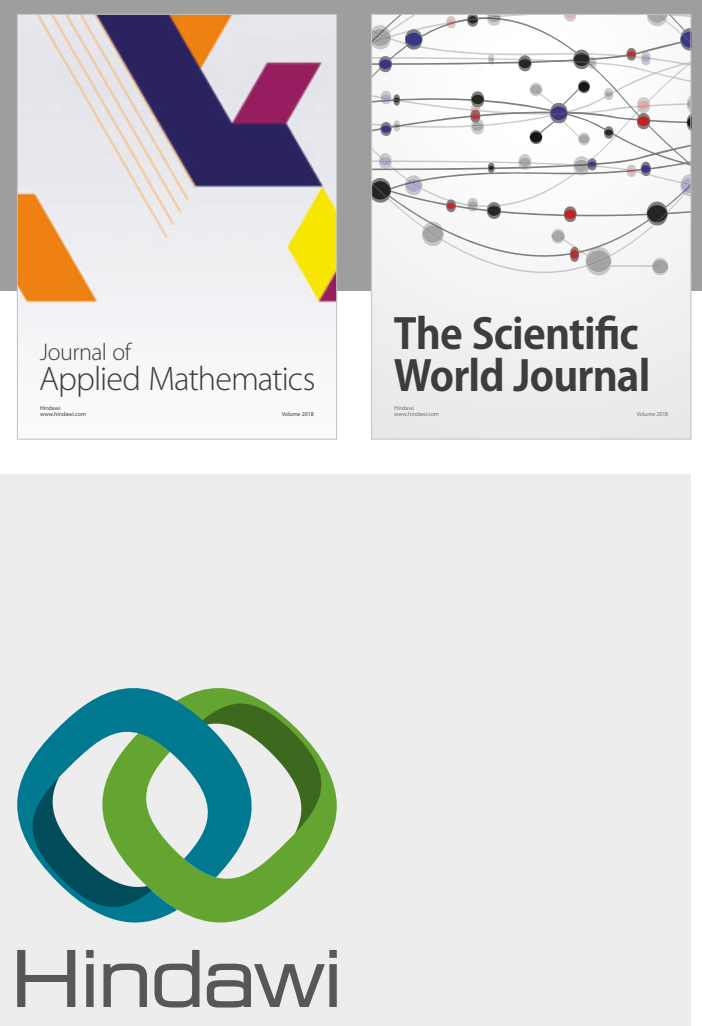

Submit your manuscripts at

www.hindawi.com

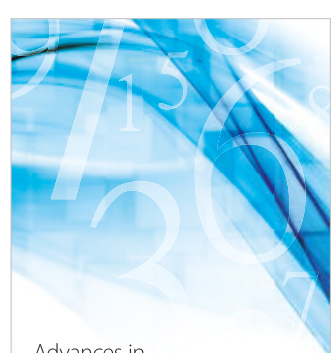

Advances in
Numerical Analysis
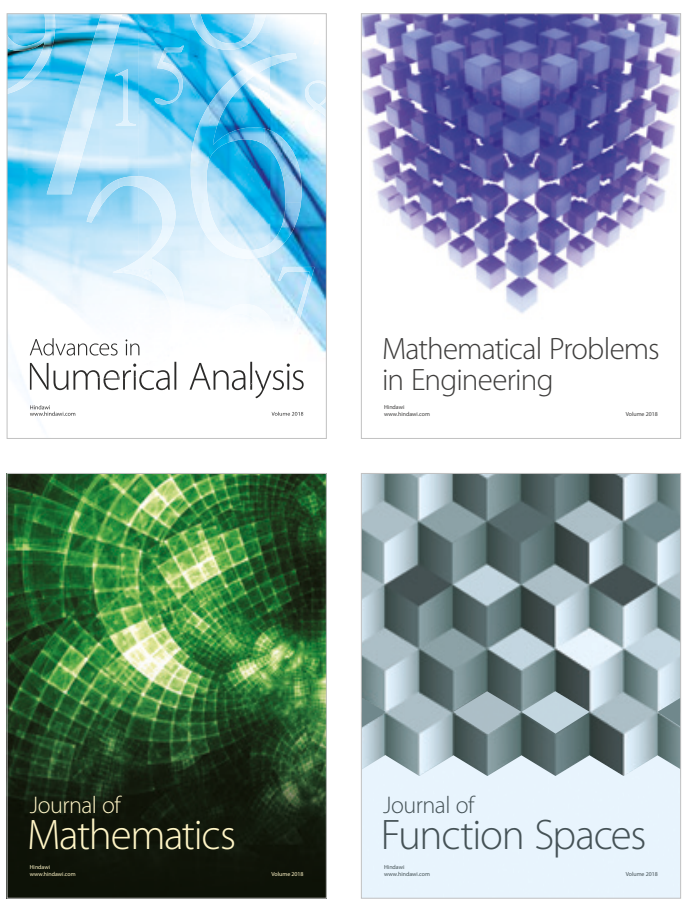

Mathematical Problems in Engineering

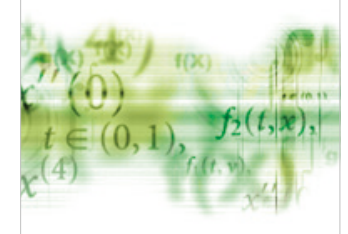

International Journal of

Differential Equations

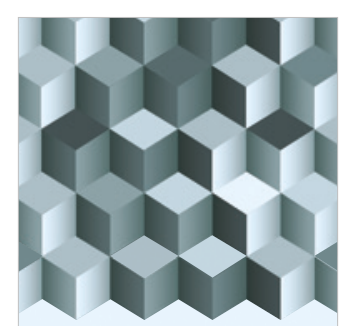

Journal of

Function Spaces
The Scientific

World Journal

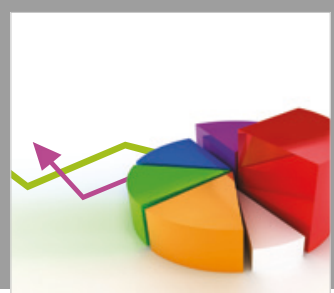

Journal of

Probability and Statistics
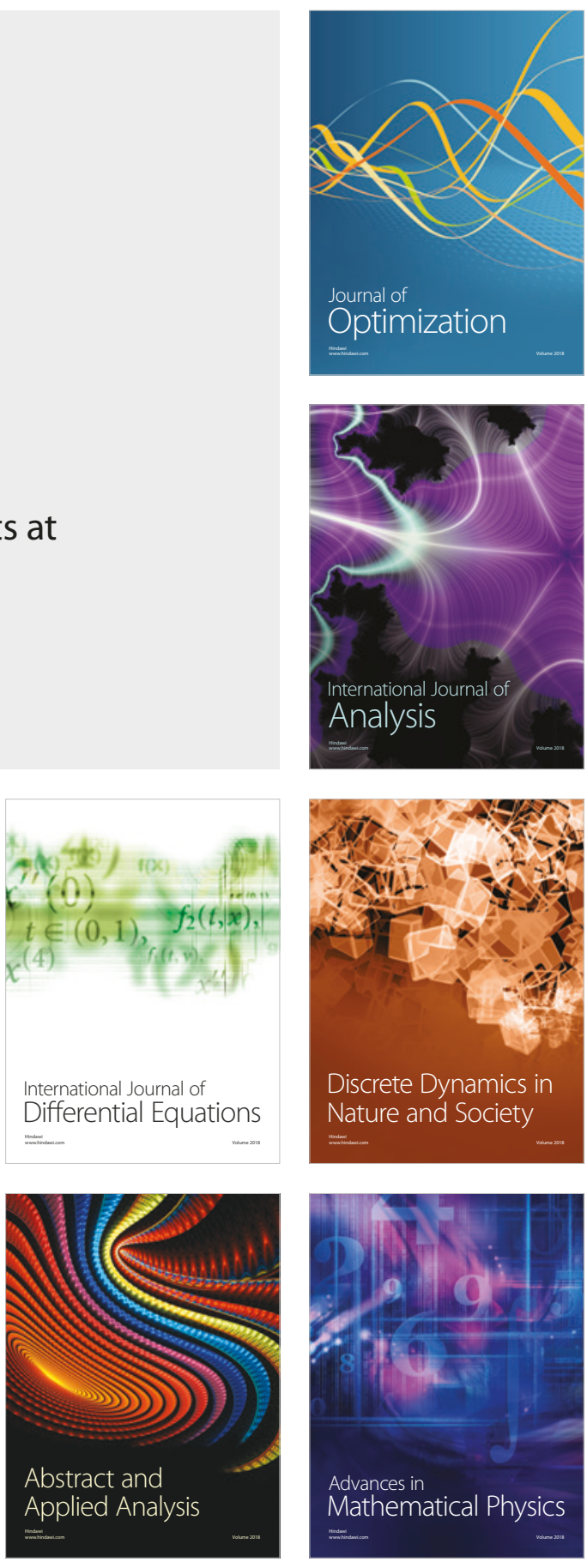